\title{
Breast Cancer Metastasis-Suppressor 1
}

National Cancer Institute

\section{Source}

National Cancer Institute. Breast Cancer Metastasis-Suppressor 1. NCI Thesaurus. Code C21506.

Breast cancer metastasis-suppressor 1 (246 aa, $\sim 28 \mathrm{kDa}$ ) is encoded by the human BRMS1 gene. This protein is involved in the negative regulation of nuclear factor kappa B-dependent gene transcription. 